Vol III. No.1, September 2018, hlm. 83 - 88

Available online at www.jurnal.una.ac.id/indeks/jmp

\title{
INTERAKSI ANTARA MODEL PEMBELAJARAN DENGAN KEMAMPUAN AWAL MATEMATIK SISWA TERHADAP KEMAMPUAN KOMUNIKASI MATEMATIS SISWA
}

\author{
Eva Margaretha Saragih ${ }^{1 *}$, Anim $^{2}$ \\ 1.2 Prodi Pendidikan Matematika Universitas Asahan \\ Email: agethaevasaragih@gmail.com,
}

\begin{abstract}
The purpose of this study is to find out whether there is an interaction between the learning model and the students 'initial mathematical abilities towards students' mathematical communication skills. This type of research is semi-experimental. This research was carried out at Al-Istiqomah Private Vocational School, Kec. Tanah Jawa. The sample of this study consisted of 2 experimental classes, namely the experimental group 1 class X SMK TKJ with the number 34 people and group 2 Experiment class X TKR with the number 34 people. The results of data analysis on the initial ability test, the students' mathematical communication ability test shows that the data is normally distributed and has homogeneous variance. Furthermore, to answer the problem formulation, two-way ANAVA is used. From the results of ANAVA calculation, it can be concluded that: There is an interaction between the learning model and the students 'initial mathematical abilities towards students' mathematical communication skills.
\end{abstract}

Keywords: Interaction, Initial ability, mathematical communication

\begin{abstract}
Abstrak
Tujuan penelitian ini untuk mengetahui apakah terdapat interaksi antara model pembelajaran dengan kemampuan awal matematik siswa terhadap kemampuan komunikasi matematik siswa. Jenis penelitian ini adalah semi eksperimen. Penelitian ini dilaksanakan di SMK Swasta Al-Istiqomah Kec. Tanah Jawa. Sampel penelitian ini terdiri dari 2 kelas eksperimen yaitu kelompok eksperimen 1 kelas $\mathrm{X}$ SMK TKJ dengan jumlah 34 orang dan kelompok Eksperimen 2 kelas X TKR dengan jumlah 34 orang. Hasil analisis data terhadap tes kemampuan awal, tes kemampuan komunikasi matematis siswa menunjukkan bahwa data berdistribusi normal dan memiliki varians yang homogen. Selanjutnya untuk menjawab rumusan masalah digunakan ANAVA dua jalur. Dari hasil perhitungan ANAVA didapat kesimpulan bahwa: Terdapat interaksi antara model pembelajaran dengan kemampuan awal matematika siswa terhadap kemampuan komunikasi matematis siswa.
\end{abstract}

Kata kunci: Interaksi, kemampuan Awal, komunikasi matematis

\section{PENDAHULUAN}

Matematika menjadi peran kunci dalam membentuk bagaimana individu menghadapi berbagai bidang kehidupan sehari-hari. Namun saat ini, seperti faktanya banyak siswa kesulitan dengan matematika dan merasa tidak puas karena mereka terus-menerus menghadapi hambatan dalam permasalahan yang disajikan. Siswa kesulitan untuk mengubah ide matematik ke dalam suatu gambar, siswa juga masih kurang mampu untuk membuat argumen dari suatu permasalahan yang berbentuk tabel atau gambar. Kesulitan-kesulitan tersebut merupakan indikator dari kemampuan komunikasi matematik siswa, sehingga disimpulkan siswa masih belum mampu meningnkatkan 


\section{MATEMATICS PAEDAGOGIC}

Vol III. No.1, September 2018, hlm. 83 - 88

Available online at www.jurnal.una.ac.id/indeks/jmp

atau mengembangkan kemampuan komunikasi matematik siswa. Pentingnya kemampuan komuniksi matematik siswa yang merupakan standar kemampuan matematik siswa yang tercantum dalam National Council of Teacher Mathematics (NCTM, 2000: 4) telah menetapkan beberapa standar proses yang harus dikuasai peserta didik dalam pembelajaran matematika, meliputi: (1) pemecahan masalah (problem solving); (2) penalaran dan pembuktian (reasoning and proof); (3) komunikasi (communication); (4) koneksi (connection);

representasi

(representations).

Hal ini jelas bahwa guru sudah selayaknya untuk memperhatikan kemampuan-kemampuan yang telah ditetapkan NCTM, salah satunya kemampuan komunikasi matematik siswa. Untuk mengembangkan atau merngsang kemampuan komunikasi matematik siswa, sangat penting untuk memahami seperti apa pengajaran matematika yang efektif, seperti apa model pembelajaran yang dilakukan,bagaimana tingkat kemampuan awal matematik siswa. Hal yang masih perlu diungkap berkaitan dengan pembelajaran matematika adalah kemampuan awal matematika siswa yang dibedakan ke dalam kelompok tinggi, sedang, dan rendah terhadap kemampuan komunikasi matematis siswa. Tes kemampuan awal diberikan kepada siswa untuk mengetahui kemampuan awal siswa sebelum siswa memasuki materi selanjutnya. kelemahan yang terjadi pada siswa dalam menyelesaikan soal matematika biasanya dipengaruhi oleh tingkat kemampuan matematika masing-masing siswa (Retna, dkk, 2013: 72). Siswa yang memiliki kemampuan matematika rendah akan memiliki lebih banyak kelemahan dibandingkan dengan siswa yang memiliki kemampuan matematika tinggi. Akibatnya, proses berpikir masing-masing siswa dalam menyelesaikan soal matematika juga berbeda bergantung pada tingkat kemampuan matematika yang dimiliki. Hal tersebut yang mengharuskan seorang guru untuk lebih kreatif lagi dalam menentukan model pembelajaran yang digunakan supaya kemmapuan awal yang dimilki siswa tidak serta merta menjadi alasan pokok utama nilai mereka tinggi ataupun rendah. Problem Based Instruction (PBI) adalah salah satu model pembelajaran yang berpusat pada siswa dan lebih memusatkan pada masalah kehidupannya yang nyata bagi siswa, peran guru hanya menyajikan masalah, mengajukan pertanyaan dan memfasilitasi dalam penyelidikan dan diskusi (Jauhari, 2011: 86). Sehingga dengan model ini siswa akan lebih termotivasi dalam menyelesaikan masalah dan pembelajaran diharapkan mampu meningkatkan kemampuan matematik siswa, selain model Problem based Learning (PBL) ada juga model pepmbelajaran yang berpusat pada siswa dan baik untuk diterapkan dalm pembelajran yaitu Model pembeljaran Contextual Teaching Learning (CTL). Johnson (2002) mengartikan pembelajaran Contextual Teaching and Learning /CTL adalah suatu proses pendidikan yang membantu siswa melihat makna dalam bahan pelajaran yang mereka pelajari dengan cara menghubungkannya dengan konteks kehidupan sehari-hari yaitu konteks lingkungan pribadinya, sosial dan budayanya. Sehingga model ini juga membantu dalam meningkatkan kemampuan komunikasi siswa dilihat dari tahapannya yang menghubungkan denga kehidupan seahri-hari sehingga siswa tidak lagi kesulitan untuk memberi argumen terhadap materi yang sudah dekat dengan kehidupan mereka.Hal ini sejalan dengan indikator komunikasi salah satunya mengubah tabel menjadi ide-ide matematik.

Selain model pembelajaran Dugaan bahwa kemampuan awal matematika siswa 


\section{MATEMATICS PAEDAGOGIC}

Vol III. No.1, September 2018, hlm. 83 - 88

Available online at www.jurnal.una.ac.id/indeks/jmp

yang dibedakan ke dalam kelompok kemampuan tinggi, sedang dan rendah juga memberi pengaruh terhadap hasil kemampuan matematik siswa. Sehingga diduga adanya interaksi dengan model pembelajaran yang pada akhirnya dapat mempengaruhi kemampuan komunikasi matematik siswa. Darmadi (Rahma, 2013: 188) mengatakan bahwa prestasi belajar merupakan hasil interaksi beberapa faktor. Hasil penelitian Anim (2016) yang menyatakan bahwa terdapat interaksi yang signifikan antara faktor pembelajaran dengan faktor kemampuan awal terhadap perbedaan kemampuan komunikasi matematis siswa. Hal Ini menunjukkan bahwa tinggi rendahnya prestasi belajar siswa tidak hanya dipengaruhi oleh model pembelajaran yang diterapkan melainkan dipengaruhi oleh faktor lain salah satunya kemampuan awal matematika siswa. sehingga pemilihan lingkungan belajar khususnya model pembelajaran menjadi sangat penting untuk dipertimbangkan artinya setiap pemilihan model pembelajaran oleh guru harus dapat meningkatkan kemampuan matematika siswa yang heterogen. (Multina,2016:2)

Berdasarkan uraian yang telah dikemukakan, maka peneliti tertarik untuk melakukan penelitian dengan judul "Interaksi Antara Model Pembelajaran Dengan Kemampuan Awal Matematik Siswa Terhadap Peningkatan Kemampuan Komunikasi Matematis Siswa."

\section{METODE}

Jenis penelitian ini adalah penelitian kuantitatif dengan model kuasi eksperimen dengan desain pembelajaran One Shot-Case Desain. Penelitian dilaksanakan di SMK swasta Al-Istiqomah Kecamatan Tanah Jawa Populasi penelitian ini adalah seluruh kelas $\mathrm{X}$ SMK swasta Al-Istiqomah Kecamatan Tanah Jawa. tahun ajaran 2017/2018. Sumber data dalam penelitian kuantitatif adalah dengan menentukan populasi dan sampel. Bila hasil penelitian digeneralisasikan maka sampel yang digunakan sebagai sumber data harus representatif dan dapat dilakukan dengan cara mengambil sampel dari populasi secara random. Penelitian ini dilakukan terhadap dua kelompok eksperimen. Pada kelas eksperimen 1 digunakan pembelajaran PBL sedangkan pada kelas eksperimen 2 digunakan model pembelajaran CTL

Tabel 1. Tabel Desain Penelitian

\begin{tabular}{lll}
\hline Grup & Variabel terikat & Postest \\
\hline Eksperimen1 & $\mathrm{X}_{1}$ & $\mathrm{O}$ \\
\hline Eksperimen2 & $\mathrm{X}_{2}$ & $\mathrm{O}$ \\
\hline
\end{tabular}

Sumber: Modifikasi Sugiyono (2012)

Sampel penelitian terdiri dari kelompok eksperimen 1 kelas X SMK TKJ dengan jumlah 34 orang dan kelompok
Eksperimen 2 kelas X TKR dengan jumlah 34 orang.

Sampel penelitian ini adalah siswa-siswa kelas X-1 dan X-3 dengan teknik 


\section{MATEMATICS PAEDAGOGIC}

Vol III. No.1, September 2018, hlm. 83 - 88

Available online at www.jurnal.una.ac.id/indeks/jmp

probability sampling. Kelas $\mathrm{X}-1$ sebagai kelas eksperimen-1 dan Kelas X-3 sebagai kelas eksperimen- 2 .

Teknik pengumpulan data dalam penelitian ini menggunakan instrumen tes kemampuan Awal Siswa yang diambil dari soal UN SMP, tes Kemampuan komunikasi matematis yang dianalisis dengan statistik inferensial dengan uji ANAVA dua jalur. Data yang diperoleh melalui tes digunakan dapat digunakan untuk melihat perbedaan kemampuan komunikasi matematis serta melihat interaksi antara pembelajaran dengan kemampuan awal yang dimiliki siswa terhadap perbedaan kemampuan komunikasi matematis.

\section{HASIL DAN PEMBAHASAN}

\section{Deskripsi Kemampuan Awal matematik siswa}

Instrumen Kemampuan awal matematik siswa yang digunakan yaitu dari soal-soal UN SMP tahun ajaran 2017/2018 diambil sebanyak 20 butir soal, selanjutnya perolehan nilainnya akan di kombinasikan dengan nilai yang diperoleh dari data sekolah. Kemampuan awal siswa terbagi atas tiga kategori yaitu tinggi sedang rendah dengan ketentuan sebagi berikut:

Tabel 2 Kriteria Pengelompokan Kemampuan Siswa Berdasarkan KAM

\begin{tabular}{ll}
\hline Kategori & Kriteria \\
\hline Tinggi & Siswa yang memiliki nilai $\mathrm{X} \geq \bar{X}+S D$ \\
\hline \multirow{2}{*}{ Sedang } & Siswa yang memiliki nilai $\mathrm{X}$ diantara kurang dari $\bar{X}+S D$ \\
& dan lebih dari $\bar{X}-S D$ \\
\hline Rendah & Siswa yang memiliki nilai $\mathrm{X} \leq \bar{X}-S D$ \\
\hline
\end{tabular}

Tabel 3. Data jumalah siswa berdasarkan kategori KAM

\begin{tabular}{llll}
\hline \multirow{2}{*}{ Kelompok Sampel Penelitian } & \multicolumn{3}{l}{ Kemampuan Awal Siswa } \\
\cline { 2 - 4 } & Tinggi & Sedang & Rendah \\
\hline Kelas Eksperimen - 1 & 6 & 22 & 6 \\
\hline Kelas Eksperimen - 2 & 6 & 23 & 5 \\
\hline
\end{tabular}

Data yang diperoleh berdasarkan tes di akhir penelitian (Posttes) kemudian nilai siswa dikelompokkan berdasarkan kemampuan awal matematik siswa (tinggi, sedang, rendah). Adapun data banyaknya siswa yang termasuk dalam kategore tinggi, sedng ataupun rendah daoat dilihat pada tabel 3 .

\section{Interaksi Model Pembelajaran dan KAM terhadap Kemampuan Komunikasi Matematis Siswa}

Uji interaksi antara faktor pembelajaran dan faktor KAM dilakukan dengan menggunakan Anava dua jalur. dan dapat dilihat pada Gambar 1 


\section{MATEMATICS PAEDAGOGIC}

Vol III. No.1, September 2018, hlm. 83 - 88

Available online at www.jurnal.una.ac.id/indeks/jmp

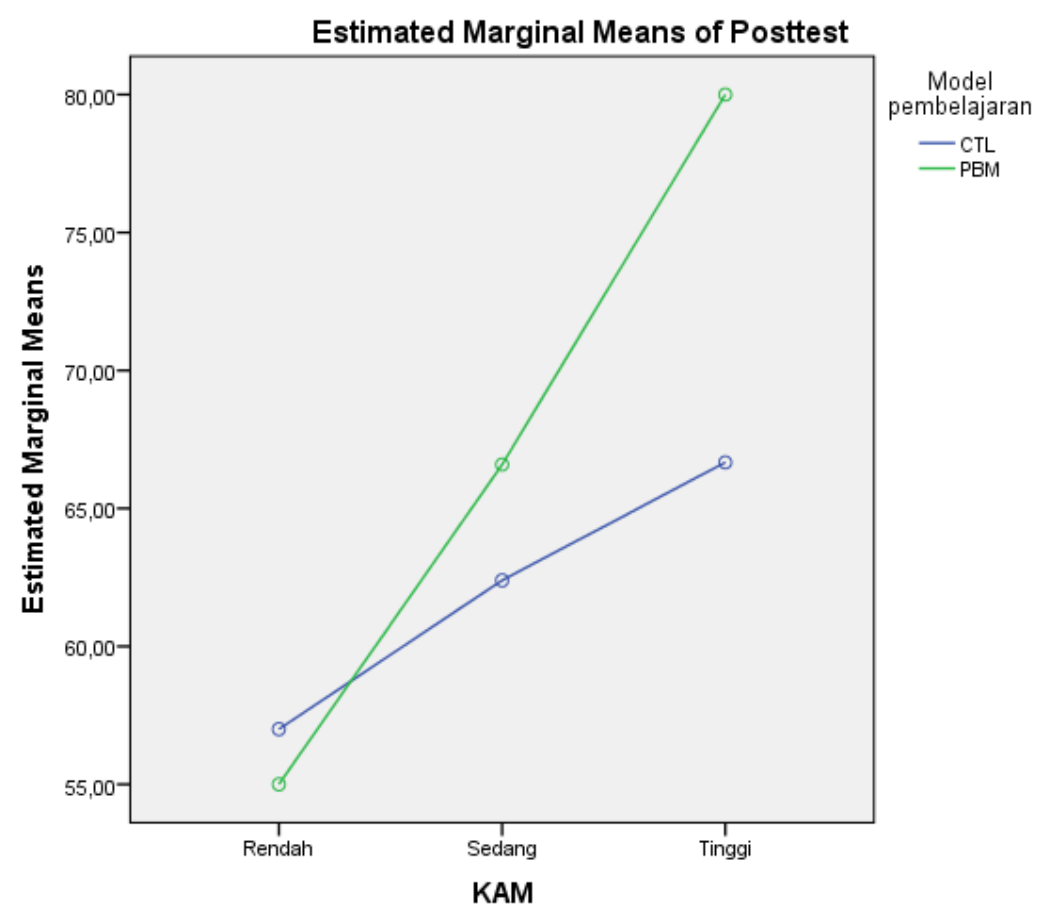

Gambar 1. Interaksi Antara Pembelajaran dengan KAM Terhadap Kemampuan Komunikasi Matematis Siswa

Berdasarkan gambar diatas terlihat bahwa terdapat interaksi antara kemampuan awal matematik siswa dengan model pembelajaran terhadap kemampuan komunikasi matematik siswa.

\section{SIMPULAN}

Dari penjelasan diatas dapat disimpulakan bahwa terlihat untuk siswa yang memiliki kemampuan komunikasi rendah lebih baik menggunakan model pembelajaran Contextual Teaching Learning (CTL), sedangkan untuk siswa yang berkemampuan komunikasi sedang dan tinggi sebaiknya menggunakan model pembelajaran Problem Based Learning (PBL). Sehingga dapat dinyatakan terlihat bahwa terdapat interaksi antara kemampuan awal matematik siswa dengan model pembelajaran terhadap kemampuan komunikasi matematik siswa.

Solusi ini dapat dijadikan salah satu alternatif untuk guru dalam memilih menentukan model pembelajaran yang harus dilakukuan terhadap siswa dengan berbagai kategori di kemampuan awal siswa.

\section{UCAPAN TERIMA KASIH}

terima kasih sebesar-besarnya peneliti ucapkan atas pendanaan penelitian dan publikasi yang dibiayai Direktorat Riset dan Pengabdian Masyarakat Direktorat Jenderal Penguatan Riset dan Pengabdian Kementerian Riset, Teknologi dan Pendidikan Tinggi Sesuai dengan Kontrak Penelitian Anggaran 2018. 


\section{MATEMATICS PAEDAGOGIC}

Vol III. No.1, September 2018, hlm. 83 - 88

Available online at www.jurnal.una.ac.id/indeks/jmp

\section{DAFTAR RUJUKKAN}

Anim. 2016. Perbedaan Kemampuan Komunikasi Matematis dan Kemandirian Belajar Siswa Menggunakan Autograph.jurnal mathematics paedagogic. Vol I. No. 1, september 2016, pg. 63 - 70. Available online at www.jurnal.una.ac.id/indeks/jmp.

Johnson, E.B. 2002. Contextual Teaching and Learning (what it is and why it's here to stay). California Thousand Oaks: Corwin Press, Inc

Multina, Mega. 2016. Perbedaan Kemampuan Penalaran dan Disposisi Matematis antara Siswa yang Diberi Model Pembelajaran Berbasis Masalah dengan Pembelajaran Bersiklus di MTsN Lhokseumawe. Medan: Tesis. Universitas Asahan
NCTM. 2000. Principles and standards for school mathematics. Virginia: United States of America. WASBN 0-87353-480-8

Rahma, A.A. 2013. Pengaruh Model Siklus Belajar Berbantuan Mind Map terhadap Prestasi Belajar Fisika Ditinjau dari Kinerja Laboratorium Siswa Kelas VIII SMPN 1 Rejoso Kabupaten Pasuruan. Jurnal Pendidikan Sains. Vol. 1, No. 2

Retna, M, Lailatul, M, dan Suhartatik. 2013. Proses Berpikir Siswa dalam Menyelesaikan Soal Cerita Ditinjau Berdasarkan Kemampuan Matematika. Jurnal Pendidikan Matematika STKIP PGRI Sidoarjo, Vol. 1, No. 2. ISSN: 23378166 